[Downloaded free from http://www.conservationandsociety.org on Thursday, August 16, 2012, IP: 98.222.182.206] || Click here to download free Android applicatior this journal

Conservation and Society 8(4): 286-291, 2010

$\underline{\text { Article }}$

\title{
The Politics of Indigeneity: Indigenous Strategies for Inclusion in Climate Change Negotiations
}

\author{
Amity A. Doolittle \\ Yale School of Forestry and Environmental Studies, New Haven, CT, USA \\ E-mail: amity.doolittle@yale.edu
}

\begin{abstract}
Indigenous environmental activists have clearly articulated their views on global climate change policy. The content of these views was explored during the 10-day 2008 World Conservation Congress (WCC) in Barcelona. Data were primarily collected through interviews and participant observation. In addition, policy statements and declarations made by indigenous environmental activists from 2000 to 2009 were analysed to place the perspectives of indigenous leaders and environmental activists in the context of their decade-long struggle to gain negotiating power at the United Nations Framework Convention on Climate Change. This study examines the rhetorical strategies indigenous leaders from around the world use to gain political recognition and legitimacy in climate change negotiations. Two core principles, relating to a particular representation of indigenous environmental knowledge are identified as fundamental rhetorical tools. These are a belief that the earth is a living being with rights and the conviction that it is the responsibility of indigenous peoples to protect the earth from over-exploitation. However, reference to indigenous environmental knowledge is not the only rhetorical mechanism used by indigenous leaders in the climate debates. When faced with specific United Nations policies to combat climate change that could have a profound impact on their land rights, some indigenous leaders adopt a more confrontational response. Fearing that new polices would reinforce historical trends of marginalisation, indigenous leaders seeking recognition in climate change debates speak less about their ecological knowledge and responsibility to the earth and more about their shared histories of political and economic marginalisation and land dispossession, experienced first through colonialism and more recently through globalisation.
\end{abstract}

Keywords: indigenous knowledge, indigenous peoples' rights, indigenous identity, climate change policy, climate justice, International Union for Conservation of Nature, political identity, colonialism

DOI: $10.4103 / 0972-4923.78142$

\section{INTRODUCTION}

Indigenous environmental leaders at the 2008 World Conservation Congress (WCC) in Barcelona came from universities, non-governmental organisations, local communities and governments. They were lawyers, farmers, religious leaders, academicians, elders, and politicians. Their diverse backgrounds represented the tremendous cultural diversity of the indigenous peoples around the world. Yet, despite this diversity of origin, they often presented a unified environmental vision. Recalling the words of her ancestor, a member of the Yaqui Indian Nation said:

'She told us many, many years ago...that we shouldn't dig the coal out of the earth, coal is the liver of our Mother Earth, and the coal needs to stay inside her body to keep her healthy' (Carmen 2008).

An Igorot indigenous leader from the Philippines spoke of her belief that failure to respect nature would have negative consequences:

'... if you have violated your forests, if you have not done the indigenous protocols... before you cut a tree or kill a deer, then of course something is going to get back to you' (TauliCorpuz 2008).

Whether from Arizona or the Philippines, from the desert or the rainforest, indigenous leaders spoke of the earth as a living being that humanity must respect.

This shared discourse highlighting the special relationship between indigenous peoples and nature has been an important

Copyright: $@$ Amity A. Doolittle 2010. This is an open access article distributed under the terms of the Creative Commons Attribution License, which permits unrestricted use and distribution of the article, provided the original work is cited. 
[Downloaded free from http://www.conservationandsociety.org on Thursday, August 16, 2012, IP: 98.222.182.206] || Click here to download free Android applicatior this journal

tool for indigenous peoples when seeking representation in international environmental negotiations and agreements like the United Nations Framework Convention on Climate Change (UNFCCC). However, it is not the only strategy, nor the only element of shared identity that they draw on.

When confronted with specific programmes to combat climate change, namely the United Nations' (UN) Reducing Emissions from Deforestation and Degradation (REDD), a preferred policy promoted widely at the WCC (Brosius \& Campbell this issue), indigenous peoples adopted a more confrontational response. Fearing that REDD policies could have a profound impact on land rights, self-determination and sovereignty, their leaders spoke ardently against the proposed REDD projects. In their critique of REDD, indigenous leaders spoke less about their relationship to the earth and their indigenous environmental knowledge and more about their shared histories of marginalisation and dispossession, first through colonialism and more recently through globalisation.

\section{POLITICAL SPACE TO DEFEND INDIGENOUS RIGHTS $^{1}$}

This study of indigenous peoples and their representatives' views on climate change policy intersects with debates over the concept of indigeneity and indigenous ecological knowledge (Li 2000; Berkes \& Jolly 2001; Kuper 2003; Dove 2006). Anthropological and ethnobotanical characterisations of indigenous environmental knowledge have demonstrated that it is a complex knowledge system deeply rooted to a place and based on a unique set of experiences (Conklin 1957; Dove 1985; Brush \& Stabinsky 1996). It is 'inherently scattered and local in character, and gains its vitality from being deeply implicated in peoples lives' (Agrawal 1995: 5, as cited in Ellen et al. 2000: 16). This view of indigenous knowledge focuses on the plurality of ways of knowing the environment and explores the importance of understanding how knowledge production is tied to place and culture.

This article does not focus on the idiosyncratic and experientially based elements of indigenous knowledge. Instead, I explore the ways that indigenous leaders use aspects of their identity and environmental knowledge to create political space for their participation in international climate change negotiations (see also Martello 2004, 2008). Looking at data from the last decade it is possible to identify several shared patterns of speech and use of metaphors that indigenous leaders rely on to create an image of authenticity and to confirm their legitimacy as caretakers of the natural world. Statements like the one below, taken from The Hague Declaration (IIPFCC 2000), are used to bolster claims of their environmental knowledge as lasting and factual and their stewardship as uncontestable:

'Earth is our Mother. Our special relationship with Earth as stewards, as holders of indigenous knowledge cannot be set aside. Our special relation with her has allowed us to develop for millennia a particular knowledge of the environment...'

A sense of belonging and special guardianship of the earth is another common rhetorical strategy. The beginning of The Anchorage Declaration is a typical example:

'We express our solidarity as Indigenous Peoples living in areas that are the most vulnerable to the impacts and root causes of climate change. We reaffirm the unbreakable and sacred connection between land, air, water, oceans, forests, sea ice, plants, animals and our human communities as the material and spiritual basis for our existence' (Indigenous Peoples' Global Summit on Climate Change 2009).

This convergence of a global dialogue on climate change and indigenous peoples' struggle for political recognition, especially in terms of control of their lands and natural resources, has created a unique opportunity for indigenous leaders. Through the reification of their indigenous identity and environmental knowledge systems, they appear to be creating a political identity (Pulido 1996; cf Jung 2008) based on their ability to sustainably manage natural resources and their perceived mandate to protect mother earth.

In the following pages, I explore the rhetorical strategies that indigenous representatives and activists from around the world use to legitimise their position in international climate negotiations. There are common ways in which values, identities and knowledge systems are simplified in order to present a unified 'indigenous worldview', a singular 'cosmovision'. This use of the concept of indigenous knowledge as a unifying principle, rather than a marker of cultural distinctiveness, underscores how discourses can shift in relation to the power and priorities of the groups involved. It also highlights that indigeneity and indigenous knowledge can be used in multiple ways to achieve political recognition and advancement (Jung 2008).

Climate change policy has become a useful organising tool for indigenous leaders in their centuries-old struggle for recognition of their sovereignty, self-determination and traditional land rights. To many indigenous leaders, climate change presents an opportunity to demand recognition of their rights and their experience-based knowledge, drawing attention to the value of their traditions and cultural systems which they believe are responsible for protecting much of the world's remaining forests. The underlying message is clear: indigenous peoples are not the ones responsible for the current condition of the environment. In the following pages, I provide descriptions of how and in what context indigenous representatives have chosen to emphasise this meta-narrative of 'indigenous peoples as stewards of the earth'. Next I explore under what circumstances this rhetorical strategy shifts from emphasising recognition justice towards drawing attention to a more radical call for redistributive justice (cf Fraser \& Honneth 2003) aimed at reversing centuries of global inequities. To achieve redistributive justice, indigenous leaders talk less of their ecological knowledge and more of the inequities they have experienced as marginalised peoples exploited by colonialism and globalisation, the same forces that are responsible for the over-exploitation of natural resources that has contributed to the present concerns over climate change. 
[Downloaded free from http://www.conservationandsociety.org on Thursday, August 16, 2012, IP: 98.222.182.206] || Click here to download free Android applicatior this journal

288 / Amity A. Doolittle

\section{RESEARCH SITE AND METHODS}

This research was part of the coordinated group ethnography of the WCC, organised by a research initiative called 'Advancing Conservation in a Social Context'. The group consisted of about two dozen social scientists from England, Canada, United States and Peru. Regular meetings allowed the group to share data and insights and made it possible to understand the Congress though a wider lens than possible as a single researcher.

The WCC, which is convened by the International Union for Conservation of Nature (IUCN), was an ideal place to explore the indigenous narrative of climate change for several reasons. First, it is the world's largest and oldest network of environmentalists, in which the private sector, nongovernmental organisations, governments, and civil society work together to define the conservation agenda. The 2008 Congress attracted a large, globally diverse audience - over 6,600 people representing 179 nations, with over 970 events (Universalia Management Group 2009).

Second, the UN General Assembly adopted the UN Declaration on the Rights of Indigenous Peoples (UNDRIP) in the previous year. Indigenous people were energised by this victory, which provided them with new political leverage in their struggles for rights and self-determination. The WCC provided a testing ground for the strength of UNDRIP in relation to environmental issues. The meetings in Barcelona also offered an important opportunity for indigenous leaders to strategise for increased visibility at the UNFCCC in Copenhagen in 2009. 'From Chico Mendez to Copenhagen: Learning from Forestry Peoples How to Make REDD Work' was just one of the many workshops at the WCC that focused on preparing indigenous leaders for the UNFCCC in Copenhagen in 2009; this was a specific goal of the Alliances Workshops organised under the Biocultural Diversity and Indigenous Peoples Journey, of which there were more than 20 events.

Finally, WCC was an ideal research site because both broader issues that concern indigenous peoples and climate change were the two central organising principles. Indigenous environmental activists were particularly interested in participating in discussions about projects for REDD, which were hotly debated at the WCC. Still a relatively new and little understood policy tool, indigenous leaders wanted to learn what positive and negative impacts REDD projects might have on their rights and forest-based livelihoods.

Data were collected at the WCC, over a ten-day period, through a variety of techniques: formal interviews, informal interactions, observations of panel presentations, attendance at negotiations, side events and the members assembly, and document review of press releases and IUCN reports. Public meetings, panels and workshops were tape recorded, making it possible to use the leaders' own voices to capture the depth of their convictions.

To add historical context and depth to data from the WCC, indigenous environmental activism was analysed from a second vantage point: the numerous press releases, policy statements and declarations on climate change made by indigenous organisations from 2000-2009. The WCC was seen as just one moment in the ongoing efforts of indigenous leaders to be gain visibility in the international climate debates.

\section{RESULTS AND DISCUSSION}

\section{'I am an indigenous person; I have a voice; I do not need help being heard."}

The International Indigenous Peoples Forum on Climate Change (IIPFCC) was established in 2000 as an open forum for all indigenous peoples who were interested in following the UNFCCC process. One of the first public statements made by the IIPFCC (2000) was The Hague Declaration. It was a direct and simple request for inclusion:

'We are profoundly concerned that current discussions within the Framework Convention on Climate Change, as well as the practical implementation of the Kyoto Protocol do not recognise our right to adequate participation. These policies and mechanisms exclude us as participants, deny our contributions, and [marginalise] our Peoples.'

Yet seven years later at the Bali Convention of Parties, and only three months after the passage of UNDRIP, indigenous representatives were barred from entering the meeting between UNFCCC Executive Secretary Yvo de Boer and civil society representatives. One of the topics under discussion was REDD, a policy approach aimed at sustainable management of forests and enhancement of forest carbon stocks in developing countries (UNFCCC 2007). REDD projects would directly impact indigenous peoples, yet there had been no opportunity for them to comment on its inclusion in the Bali Action Plan.

In principle, REDD would encourage funding from industrialised nations to support protection of forests in the developing world, thereby significantly reducing global carbon emissions. In practice, it also provided an opportunity for the industrialised nations to achieve their targets for emissions reductions by purchasing offsets from standing forests in the developing world, rather than by making costly changes within industry. Supporters called the plan a win-win scenario - biodiversity conservation, global carbon emission and forest dependent people would all benefit from a market that valued standing forests. Within days, USD 165 million was pledged by nine nations to the World Bank's newly created Forest Carbon Partnership (UNEP 2007) that was designed to assist developing countries establish REDD projects.

But as quickly as REDD was embraced as an innovative policy solution by the industrialised world, the indigenous leaders and other members of civil society began to raise concerns about the potential threats REDD might have on indigenous rights and territories (Griffith 2007; Goldtooth 2009). It appeared that what many in the industrialised world saw as part of the solution to climate change-creating a market in tradable carbon rights-was perceived very differently by the indigenous peoples. Recognising that win- 
[Downloaded free from http://www.conservationandsociety.org on Thursday, August 16, 2012, IP: 98.222.182.206] || Click here to download free Android applicatior this journal

win scenarios are rare if not non-existent, indigenous leaders knew there would be trade-offs.

In response to the plans of the 2007 UNFCCC to develop REDD policies, the following statement was issued by the IIPFCC (2007):

'REDD will not benefit Indigenous Peoples, but in fact will result in more violations of our Human Rights, our Rights to our lands, territories and resources, steal our land, cause forced evictions.... Under REDD, States and Carbon Traders will take more control over our forests.'

No longer were indigenous representatives simply asking for inclusion in the negotiations as they had in The Hague Declaration in 2000. In the 2007 IIPFCC statement, attention was focused on the possibility that proposed climate policies would result in further injustices towards indigenous peoples and would violate one of the central elements of the UNDRIP: the right to freely choose their own destiny.

'There is a black smoke that is flowing to my people, and it is the smoke of death. ${ }^{3}$

During the WCC, over 50 forum events dealt with issues relating to indigenous rights. In the many events organised around the topic of indigenous rights and climate change, five central issues emerged. Three of these dealt with land rights, self-determination, and the over-exploitation of resources by industrialised nations. Two additional concerns, however, generated the most heated debates and impassioned speeches. The first major concern was the conviction that REDD would simply provide opportunities for the already wealthy and powerful nations to profit, while indigenous peoples' rights were further violated. The second major concern was dismay that the global north might be able to avoid reducing their own carbon emissions by simply buying the rights to carbon in developing countries. To many indigenous representatives, this felt like the latest form of colonialism in which their resources were to be extracted to benefit other nations. The potential trade-offs associated with REDD were unbalanced-and not in the favour of indigenous peoples.

In a panel discussion on 'Local and Indigenous Peoples and REDD', the two concerns of land rights and self-determination were voiced by an Ecuadorian indigenous representative (Cerna 2008):

'When talking with other indigenous groups about REDD, most say it is not the money they are interested in. We may need the money, but what we want is to be granted legal rights within our territories, to be able to exercise our rights. We want to continue with our plans, to strengthen our self-government, to improve our education system and our forest management practices. Yes, we need resources to do all that, but let's not make the REDD discussion about the money. It's not... money will lift us out of poverty...that is not the way...the vision has to come from within our own communities.'

After centuries of subjugation under colonial rule, indigenous leaders take every opportunity to assert their independence and claim their ability to mange their resources according to the will of their communities. Determining the best path for their communities depends on finding the right balance between economic growth and the sustainable use of resources. At the WCC, the dominant feeling among indigenous representatives was that a top-down implementation of REDD projects would not allow for this vision.

When discussions turned to the history of extraction of raw material by the global north, a more pessimistic and cynical tone emerged. In contrast to the narratives that highlighted indigenous peoples' role as caretakers of the earth, stories were presented describing the destruction of indigenous lands caused by people external to their communities. These stories were organised around the creation of a category of 'other'the non-indigenous peoples of the world-who destroy the environment. According to Chief Tony James (2008), a Wapichan from Guyana:

'The concessions to mining companies are coming into [our]... areas, with bulldozers and excavators. During the rainy season the heavy machinery created drainage and gutters in the area. In the process of looking for more money, contractors first broke bridges and went into the headwaters of creeks and rivers...spoiling the fish hatching areas. The governmental agency in charge of mining did not even tell us.'

To Chief Tony James and other indigenous leaders, stories like these are symbolic of the relationship they have with the developed world - just as forests are violated, so are the rights of the indigenous peoples.

With the passage of UNDRIP, indigenous peoples theoretically have a legal instrument that should protect them from situations like those described by Tony James. It should no longer be possible for outside organisations to extract resources from indigenous territories without free, prior and informed consent from the community. However in some countries, like Indonesia, it is unlikely that indigenous peoples can rely on UNDRIP for legal protection. Norman Jiwan from Indonesia described the abuses against indigenous rights that are taking place as a result of efforts to develop the oil palm industry. ${ }^{4}$ According to Jiwan (2008):

'We documented the appropriation of indigenous lands, failure to recognize indigenous governance and land rights, burning even of our longhouse in the struggle with palm interests. [There were] 514 conflicts between non-indigenous and indigenous people...even murder of villagers!'

Jiwan concluded his talk asserting that 'development without justice is not development.' After many other stories of injustices that resulted in the loss of land rights, Chief Tony James (2008) asked the key question: 'Will carbon trade follow this pattern?'

Land rights, self-determination and the over-exploitation of resources by the global north were significant concerns for indigenous representatives, but they were also the least controversial of their platforms for climate policy. A more pointed critique of current climate policy came from indigenous representatives who believe that initiatives like REDD supported the continuation of historical global inequities between the developed and developing world. It was believed that once industrialised countries were finished with extracting resources from their territories, they would then benefit from REDD projects: 
[Downloaded free from http://www.conservationandsociety.org on Thursday, August 16, 2012, IP: 98.222.182.206] || Click here to download free Android applicatior this journal

\section{0 / Amity A. Doolittle}

'Those who are destroying today, the timber companies, those who are destroying the environment are in our territories, threatening and extracting all there is and making lots of money. And those who already did it before are seeking funds from the government to recover that which they destroyed.... They know the government has funds to recover degraded lands... but they degraded them themselves! And governments are seeking funds to pay them.'

'So they win twice!' concluded Mauricio Paba Florez (2008).

Finally indigenous leaders were most angered by the possibility that industrialised nations could use policies like REDD to avoid their responsibility to reduce carbon emissions in their own countries by purchasing offsets in the developing world. This view is best expressed in 2008 in the Accra Caucus Statement COP14.

'Corporations that contribute to deforestation and forest degradation should not benefit from REDD mechanisms. REDD mechanisms must not provide opportunities for big businesses to exploit rainforest nations that participate in REDD schemes. REDD must not be used as a legal excuse for industrialized countries to continue polluting. It must be accompanied by deeper commitments from industrialized countries to reduce their own emissions' (Anon 2008, emphasis in original).

The possibility that REDD policies could simply reinforce existing global power structures was by far the greatest concern that indigenous leaders voiced about REDD. In this context, where anger over past and future injustices is at its peak, climate change policy that did not include their rights was a symbol of continued colonial oppression. Two slogans used by indigenous representatives at the WCC directly speak to the link they see between continued colonialism and carbon markets:

'Alto al imperialismo del carbon!' (Cease carbon imperialism!)

'Stop $\mathrm{Co}_{2}$ lonialism. Support Indigenous Peoples Rights, Oppose Carbon Trading!'

\section{CONCLUSION AND FUTURE RESEARCH}

This essay has explored the dominant rhetorical strategies used by indigenous leaders seeking participation in climate change negotiations. I asked the question: How have indigenous leaders legitimised their claims for participation in the global climate change negotiations? The most prevalent stance of indigenous leaders has been to focus on a shared discourse that essentialises indigenous knowledge. Their narratives, metaphors and stories about the earth can be understood as rhetorical devices that allow them to authenticate and validate their role as legitimate and knowledgeable participants in the climate change negotiations. As such, this rhetorical strategy takes a positive stance: indigenous leaders argue that they have valuable knowledge to contribute to the climate discussion.

However, as debates at the WCC about REDD suggest, specific programmes designed to combat climate change are countered not by the discourse of shared indigenous knowledge, but by more radical rhetoric that emphasises indigenous peoples' shared historical experiences of exploitation. This rhetorical strategy builds not on the added value of indigenous environmental knowledge to the management of natural resources, but on a demand for redistributive justice for centuries of land dispossession and exploitation. In short, by focusing on past injustices, indigenous leaders are demanding transformative change in climate polices that will address the long-standing inequities they have endured and which they feel have contributed to the existing conditions of climate change. It remains unclear whether either arguments will have long-lasting impacts on REDD policies.

Tracing the dynamic shifts in the rhetorical strategies of indigenous leaders as they manoeuvre within the international climate change debates raises important questions about both the power and the limitations of identity politics as a means of influencing the politics of climate change on a large scale. The paper has looked at two different elements of shared indigenous identities that have been useful organising tools for indigenous leaders in their efforts to legitimise their claims as rightful participants in the climate change negotiations. Whether or not indigenous leaders may ultimately need to transcend identity politics by seeking and finding alliances with other groups, perhaps with groups concerned more broadly with equity and human rights, is an unanswered question. Whether and in what manner this might occur in the context of the climate change negotiations is a rich and substantive subject area for scholars of social movements, environmental justice, environmental politics and indigenous rights to explore.

\section{ACKNOWLEDGEMENTS}

I would like to thank two anonymous reviewers for their invaluable comments, Peter Brosius for involving me in the project, and Lisa Campbell and Dan Brockington, the guest editors of the series. Intellectual support for this project was provided by Advancing Conservation in a Social Context (ACSC), a research initiative supported by the John D. and Catherine T. MacArthur Foundation. Financial support was provided by Yale School of Forestry and Environmental Studies. This report has also benefited from feedback from my students at Yale and from participants of a workshop organised by of the Department of Social Anthropology at the University in Oslo.

\section{Notes}

1. This is the primary mission of A Coordenação das Organizações Indígenas da Amazônia Brasileira-COIAB, Marcos Apurina. Community forest tenure, governance and benefits: The missing link to climate mitigation and adaptation. Alliances Workshop World Conservation Congress, Barcelona. October 8, 2008.

2. This section title draws from a statement made by Aroha Mead, a Maori from New Zealand and senior lecturer at Victoria University, at the beginning of her campaign speech for Chairperson of the Commission on Environmental, Economic and Social Policy. October 5, 2008.

3. Florez 2008. The prophecy was attributed to a Yanomami elder.

4. See Doolittle (2007) for additional evidence of similar violations of human rights by the managers of oil palm plantations in Sabah, Malaysia. 
[Downloaded free from http://www.conservationandsociety.org on Thursday, August 16, 2012, IP: 98.222.182.206] || Click here to download free Android applicatior this journal

Indigenous strategies for inclusion in climate change negotiations / 291

\section{REFERENCES}

Agrawal, A. 1995. Indigenous knowledge and scientific knowledge: Some critical comments. Indigenous Knowledge and Development Monitor 33(3): 3-6

Anon. 2008. Accra Caucus on Forests and Climate Change, Civil Society Strategy Meeting. Poznan, Poland, 30 November-1 December 2008, Accra Caucus Statement for COP 14. http://www.redd-monitor. org/2008/12/08/accra-"caucus-statement-on-forests-and-climatechange. Accessed on April19, 2009.

Berkes, F. and D. Jolly. 2001. Adapting to climate change: Social-ecological resilience in a Canadian western Arctic community. Conservation Ecology 5(2): 18.

Brush, S. and D. Stabinsky. (eds.). 1996. Valuing local knowledge: Indigenous people and intellectual property rights. Washington DC: Island Press.

Carmen, A. 2008. When contemporary science and indigenous knowledge collide. In: Alliances Workshop. World Conservation Congress, Barcelona. October 7, 2008.

Cerna, J. 2008. Local and indigenous people and REDD. UNDP Poble discussion. World Conservation Congress, Barcelona. October 8, 2008.

Conklin, H.C. 1957. Hanoo agriculture: A report on an integral system of shifting cultivation in the Philippines. FAO Forestry Development Paper No. 12.

Doolittle, A. 2007. Native land tenure, conservation, and development in a pseudo-democracy: Natural resource conflicts in Sabah, Malaysia. Journal of Peasant Studies 34(3): 474-497.

Dove, M. 1985. Swidden agriculture in Indonesia: The subsistence strategies of the Kalimantan Kantu. New York: Mouton.

Dove, M.R. 2006. Indigenous people and environmental politics. Annual Review of Anthropology 35: 191-208.

Ellen, R., P. Parkes and A. Biker. 2000. Indigenous knowledge and its transformations. New York: Routledge.

Fraser, N. and A. Honneth. 2003. Recognition and redistribution? A politicalphilosophical exchange. London: Verso Books.

Florez, M.P. 2008. Local and indigenous people and REDD. UNDP Poble discussion. World Conservation Congress, Barcelona. October 8, 2008.

Goldtooth, T. 2009. Report calls for rejection of REDD in climate treaty. Indigenous environmental network. http://west.actforclimatejustice. org $/ 2009 / 10 / 456 /$. Accessed on October 10, 2009.

Griffiths, T. 2007. Seeing 'RED’? 'Avoided deforestation' and the rights of indigenous peoples and local communities. Forest Peoples Programme. Moreton-in-Marsh, UK. http://www.forestpeoples.org/sites/fpp/files/ publication/2010/08/seeingreddupdatemay09eng.pdf. Accessed on June 16, 2009.

IIPFCC. 2000. The Hague Declaration of the Second International Forum of Indigenous Peoples and Local Communities on Climate Change, November 11-12, 2000. www.tebtebba.org/index.php?option=com docman\&task $=$ doc download\&gid $=71 \&$ Itemid $=27$. Accessed on April
19, 2009.

IIPFCC. 2007. Statement by the International Forum of Indigenous Peoples on Climate Change on 'reduced emissions from deforestation and fores degradation' (REDD) agenda item at the UNFCCC climate negotiations. The $13^{\text {th }}$ Session of Conference of the Parties to the UNFCCC SBSTA 27, agenda item 5/REDD. http://www.indigenousclimate.org/index. php?option $=$ com_content $\&$ view $=$ article $\&$ id $=59 \&$ Itemid $=60 \&$ lang $=$ en. Accessed on June 16, 2009.

Indigenous Peoples' Global Summit on Climate Change. 2009. The Alaska Declaration. Anchorage, Alaska. April 24, 2009. http://www. indigenoussummit.com/servlet/content/declaration.html. Accessed on October 12, 2009.

James, T. 2008. Community forest tenure, governance and benefits: The missing link to climate mitigation and adaptation. Alliances Workshop World Conservation Congress, Barcelona. October 8, 2008.

Jiwan, N. 2008. Community forest tenure, governance and benefits: The missing link to climate mitigation and adaptation. Alliances Workshop. World Conservation Congress, Barcelona. October 8, 2008.

Jung, C. 2008. The moral force of indigenous politics: Critical liberalism and the Zapatistas. Cambridge: Cambridge University Press.

Kuper, A. 2003. The return of the native. Current Anthropology 44(3): 389-402.

Li, T.M. 2000. Articulating indigenous identity in Indonesia: Resource politics and the tribal slot. Comparative Studies in Society and History 42(1): 149-179

Martello, M.B.L. 2004. Expert advice and desertification policy: Past experience and current challenges. Global Environmental Politics 4(3): 85-106.

Martello, M.B.L. 2008. Arctic indigenous peoples as representations and representatives of climate change. Social Studies of Science 38(3): 351-376.

Niezen, R. 2003. The origins of indigenism: Human rights and the politics of identity. Berkeley: University of California Press.

Pulido, L. 1996. Ecological legitimacy and cultural essentialism: Hispano grazing in the Southwest. Capitalism Nature Socialism 7(4): 37-58.

Tauli-Corpuz, V. 2008. When contemporary science and indigenous knowledge collide. Alliance Workshop. World Conservation Congress, Barcelona. October 7, 2008.

UNEP. 2007. The Environment in the news. http://www.unep.org/cpi/ briefs/2007Dec14.doc. Accessed on June 16, 2009.

UNFCCC. 2007. Decision -/CP.13. Reducing emissions from deforestation in developing countries: approaches to stimulate action. (Advanced unedited copy). http://unfccc.int/files/meetings/cop_13/application/pdf/ cp_redd.pdf. Accessed on June 16, 2009.

Universalia Management Group. 2009. Evaluation of the Barcelona World Conservation Congress, Final Report, Volume 1. http://cmsdata.iucn. org/downloads/wcc_evaluation_final_report_16cs.pdf. Accessed on June 16, 2009. 